\title{
The Challenge of Regional Connectivity in Central, South and West Asia Dr. Moonis Ahmar*
}

\begin{abstract}
This paper will examine in detail how the vision of regional connectivity in Europe got an impetus and as a source of inspiration in other parts of the world including South, Central and West Asia. Why the two regional organisations South Asian Association for Regional Cooperation (SAARC) and Economic Cooperation Organisation (ECO), despite ambitious plans for regional cooperation and connectivity, have been unable to transform their vision into a reality? This paper will also analyse prospects and impediments in forging regional connectivity in the three Asias. What lessons can be learned by the leaders of Central, South and West Asia from the experience of Europe in transforming their conflict and violent-ridden continent into a peaceful and stable place. Taking the thread from there, the paper will also examine how Pakistan can benefit from regional connectivity in terms of Turkmenistan-Afghanistan-Pakistan-India (TAPI) gas pipeline and Central Asia, South Asia (CASA) energy corridor. The challenges of connectivity in the three Asias will be examined analytically and with a critical thinking in this paper.
\end{abstract}

Keywords: Connectivity, SAARC, ECO, TAPI, CASA, Regionalism, Regional Cooperation, Three Asias

\footnotetext{
* Dr. Moonis Ahmar is former Dean Faculty of Social Sciences and Meritorious Professor at the Department of International Relations, University of Karachi. He was also Chairman, Department of International Relations University of Karachi and is Director, Program on Peace Studies and Conflict Resolution.
}

@ 2021 by the Islamabad Policy Research Institute.

IPRI Journal $\square \mathrm{XXI}$ (1): 123-139

https://doi.org/10.31945/iprij.210105

IPRI JOURNAL $\mathbf{\square} 2021$ 


\section{Dr.Moonis Ahmar}

\section{Introduction}

7 rom any standpoint, regionalism can be called as the 'wave of the

future.' It has the ability to promote economic, political and security cooperation through a process of meaningful cooperation and connectivity. In the post Second World War era, the phenomenon of regionalism ${ }^{1}$ got an impetus with the emergence of new states in Asia and Africa. The surge of regional organisations after the WWII, the world order reflected how people living in different regions of the world realised the need to deal with critical issues ranging from climate change, global warming, food, energy, water shortages along with the other threats to human security.

The vision to transform Central, South and West Asia, as a power house, needs to be examined from a realist paradigm. When Robert Schuman, the former French foreign minister, presented a plan on May 9, 1950 , to establish a single authority for controlling the production of steel and coal in France and in the then West Germany, that plan became a basis of the European Coal and Steel Community (ECSC) 1952, European Economic Community (EEC), 1957, ${ }^{2}$ and European Union, 1993. The 1963 Franco-German Treaty of Peace and Cooperation, signed by the then French President Charles de Gaulle and the West German Chancellor Konrad Adenauer, paved the way for regional connectivity in travel, capital, goods and services in Europe. It was the forward looking approach of the European leaders which paved the way for eliminating restrictions on the free movement of people, goods, services and capital.

This paper will examine in detail how the vision of regional connectivity in Europe got an inspiration in other parts of the world including South, Central and West Asia and why the two regional organisations, South Asian Association for Regional Cooperation (SAARC) and Economic Cooperation Organisation (ECO), despite ambitious plans for regional cooperation and connectivity, are unable to transform their vision into a reality? This paper will also analyse prospects

\footnotetext{
${ }^{1}$ For a comprehensive discussion on regionalism see, Moonis Ahmar "Regionalism: Myth or Reality?" in Moonis Ahmar (ed.), The Restructuring of SAARC (Karachi: Department of International Relations, University of Karachi in collaboration with the Hanns Seidal Foundation, Islamabad, 2010), pp. 1-17.

${ }^{2}$ Albert S. Lidemann, A History of Modern Europe from 1815 to the present (West Sussex: Blackwell publishing, 2013).
} 
and impediments in forging regional connectivity in the three Asias and what lessons can be learned by the leaders of Central, South and West Asia from the experience of Europe in transforming their conflict and violent-ridden continent to peaceful and stable region.

Following questions will be examined and responded in this paper viz:

1. What is regionalism and how it emerged as a 'wave' of the future?

2. What are the areas of connectivity between Central, South and West Asia and why the three regions are unable to forge meaningful regional cooperation?

3. Why SAARC and ECO have not been able to unleash the process of regionalism in the three Asias? How can the two regional organisations play a pivotal role to augment the process of meaningful economic, political and other areas of cooperation?

4. How violence and armed conflict in Afghanistan is a major impediment for peace and regional connectivity in the three Asias?

5. What are the prospects of promoting regionalism in the three Asia?

Furthermore, the paper will dwell at length how the process of regional cooperation in Europe was a source of inspiration in South Asia? Why despite enormous opportunities for connectivity in Central, South and West Asia, SAARC and ECO representing the three regions failed to learn lessons from the success of the European Union?

\section{Regionalism: Myth or a Reality?}

How the world changed in the last 100 years, particularly since 1945 and 1991 , needs to be analysed in the context of the proliferation of states and surging of issues threatening the survival of mankind. The phenomenon of regionalism got an impetus because of the realisation that without proper cooperation and coordination, people living in a particular region cannot cope with the environmental and human security challenges.

The concept of regionalism needs to be examined in some details in order to dwell as to how this phenomenon impacts the three Asias. "Regionalism is also called as regional integration. The term is widely 


\section{Dr.Moonis Ahmar}

used in international politics with implications on the foreign policy of nation-states. Regionalism can be simply defined as a process of establishing alliances/organisations at regional level among different countries." 3 Since regionalism is a process which requires substantial political will and determination among countries belonging to that region, a feeling of oneness and nationalism also exists in order to give a practical shape to forming a regional organisation.

Penguin Dictionary of International Relations defines "regionalism is to a region what nationalism is to a nation. A complex of attitudes, loyalties, and ideas which concentrates the individual and collective minds of people(s) upon what they perceive as 'their' region. Regionalism exists both within states and between states. Within states it can be one manifestation of ethnic nationalism and the political goal of separatism and independence. Between states, regionalism is positively correlated with the idea of region." " Key concepts in International Relations states that "the term regionalism refers to intensifying political and/or economic processes of cooperation among states and other actors, geographic regions in particular, although it is most often discussed in the context of trade flows. The term regional cooperation is defined as the growth of social and economic interaction and of regional identity and consciousness. Regionalism results from the increasing flow of goods, people and ideas within spatial entity, which thus becomes more integrated and cohesive." "Regionalism pertains to a particular region. When states come together and form an organisational association at the regional level to attain specific objectives, regional arrangements are born." From historical point of view;

"the trend toward regionalism and regional arrangements is one of the most interesting developments in recent International Relations. This trend is, in part, an outcome of the necessity of pooling national resources for protection in

\footnotetext{
${ }^{3}$ Mansoor Akbar Kundi, A learner's dictionary of International Relations (Karachi: Faridi Book Center, 2006), p. 219.

${ }^{4}$ Graham Evans and Jeffrey Newnham, The Penguin Dictionary of International Relations (New York: Penguin Books, 1998), pp. 473-74.

${ }^{5}$ Martin Griffiths and Terry O' Callonghan, Key Concepts In International Relations (New York: Routledge, 2004), pp. 273-74.

${ }^{6}$ Muhammad Asif Malik and Nasrullah Khan, International Relations Theory and Practice (Lahore: Publishers Emporium, 2014), p. 349.
} 
The Challenge Of Regional Connectivity In Central, South And West Asia

a divided and war-threatened world; but it is also an outgrowth of other pressures which are driving nations together in the present era. Indeed, it may indicate that the nation-state system, which has been the dominant pattern of International Relations for some four centuries, is evolving towards a system in which regional groupings of states will be more important than the independent sovereign units. "7

Furthermore, regionalism 'refers to the growth of societal integration within a region and to the often undirected processes of social and economic interaction. Regionalism can also involve increasing flow of the people, development of multiple channels and complex networks by which ideas, political attitudes and ways of thinking spreads from one area to another and the creation of a transnational regional civil society." "In the context of International Relations;

"regionalism is the concept of organising states and dependent areas on a regional basis. In International Relations, a region is invariably an area embracing the territories of three or more states. They are bound by ties of common interests as well as of geography. In other words, regions and organisations are not necessary congruent. In its essence, the main debate about regionalism is whether it is leading to a more polarised or more cooperative world economy and world order. The relationship between regionalism and a multitasked system is a complex one, and it is becoming more complex as the number and the scope of regional initiatives increase."

Likewise, "regionalism is the process of forming a region, whether as a political project or through a spontaneous process. In other words, it is an autonomous process which means interdependence of a geographical

\footnotetext{
${ }^{7}$ Norman D. Palmer and Howard C. Perkins, International Relations: The World In Transition (Delhi: Aitbs Publishers, 2015), p. 558.

${ }^{8}$ Andrew Hurrell, "Regionalism in Theoretical Perspective" in Louis Fawcett and Andrew Hurrell (eds.), Regionalism in World Politics Regional Organisations and International Order (Oxford University Press, 1995), p. 40

${ }^{9}$ Prakesh Chandra, International Politics (New Delhi: Vikas Publishing House Pvt Ltd, 1977), p. 183.
} 
region. It is driven not by the state policies, as those of markets, trade and investment flows." 10

Regionalism promotes positive thinking and approaches for peace and cooperation but one cannot expect regionalism to take a practical shape unless ten requirements are met:

1. Political will.

2. Determination.

3. Commitment.

4. Clarity.

5. Consistency.

6. Positive approach.

7. Program.

8. Practical and pragmatic approach.

9. Leadership role.

10. Neutralising enemy images.

As far as the three Asias are concerned, the concepts and requirements of regionalism can be examined as to what extent the three regions can benefit from the wave of the future. Application of regionalism in Europe, South East Asia and elsewhere cannot be replicated in Central, South and West Asia because of structural contradictions. However, the three regions, which are inter-connected, can certainly learn lessons from such models. The two regional organisations covering the three Asias i.e. SAARC and ECO were formed several decades ago ${ }^{11}$ and are still unable to render positive results. If SAARC has become a victim of Indo-Pak conflicts, ${ }^{12}$ ECO, unlike SAARC, has power

\footnotetext{
${ }^{10}$ Maqsudul Hasan Nuri, "The Challenge of Regionalism In the Contemporary World" in Moonis Ahmar (ed.), The Restructuring of SAARC (Karachi: Department of International Relations, University of Karachi in collaboration with the Hanns Seidel Foundation, Islamabad, 2010), p. 17.

${ }^{11}$ SAARC and ECO were established in 1985.

12 The $19^{\text {th }}$ SAARC summit which was scheduled to be held in Islamabad from November 15-19, 2016, was postponed because India along with Afghanistan, Bhutan and Bangladesh refused to participate in that event on account of variety of reasons but primarily Indian stance on what it alleged Pakistan's involvement in its occupied territory of Jammu \& Kashmir. Bangladesh blamed Pakistan of its interference in its internal affairs. Afghanistan expressed its inability to attend SAARC summit in Islamabad because of increased level of violence and terrorism in its country and Bhutan refused to attend SAARC summit because of what it called as recent escalation of
} 
symmetry. However, because of the non-serious and non-professional attitude of member states along with instability in Afghanistan and American sanctions against Iran, it has not been able to play a meaningful role.

In view of the growing need to forge connectivity for augmenting economic, commercial, trade, environmental, educational and scientific cooperation in today's world, regionalism is not a myth but a reality. It needs to be examined in the context of present and future challenges faced by Central, South and West Asia.

\section{The Challenge of Regional Connectivity}

Geographically, Central, South and West Asia are inter-connected but lack vibrant economic, commercial, trade, educational, cultural and connectivity in science and technology. Stretching from Turkey to Bangladesh and Kazakhstan to Sri Lanka, the three Asias ${ }^{13}$ consist of huge land mass with a combined population of around 2 billion people. ECO composed of Iran, Pakistan and Turkey, was established as a successor of Regional Cooperation for Development (RCD) ${ }^{14}$ in 1985. In 1992, ECO was expanded with the inclusion of six states namely Afghanistan, Tajikistan, Turkmenistan, Kyrgyzstan, Kazakhstan and Uzbekistan. That bloc got a boost with the emergence of independent Central Asian states following the disintegration of USSR in December 1991.

The idea of South Asian regional cooperation, which was conceived by the former President of Bangladesh Zia-ur-Rehman in 1978, was transformed into a reality in December 1985, on the occasion of its first summit held in Dhaka. As compared to ECO, SAARC performed better in terms of identifying several areas of cooperation and holding around two dozen summits. ECO on the other hand, is not like SAARC, a victim of Indo-Pak conflicts. It failed to proceed for strategising connectivity and regional cooperation. Afghanistan and Pakistan are

terrorism in South Asia. As a result since 2016, SAARC is in limbo, as neither the summit nor meeting of Foreign Ministers has been held.

${ }^{13}$ Moonis Ahmar, "The emergence of three Asias" in World Affairs (New Delhi) vol.2. no. 2, April-June 1998, pp. 122-139.

${ }^{14}$ RCD was formed in July 1964 and lasted till the outbreak of Islamic Revolution in Iran in January 1979. It was then transformed as ECO in 1985.

https://www.semanticscholar.org/paper/The-Formation-of-RCD\%3A-RegionalCooperation-for-Ye\%C5\%9Filbursa/a03d696f10d63b03df71467c015053c735549b7a accessed on April 27, 2020. 


\section{Dr.Moonis Ahmar}

simultaneously in ECO and SAARC and act as a bridge between South, Central and West Asia. Unfortunately, violence and armed conflicts in Afghanistan are a major impediment for the task of regional connectivity in the three Asias. Without establishing peace in that war-torn landlocked country, one cannot expect stability and peace in Central and South Asia. The challenge of regional connectivity in the three Asias needs to be understood by examining four major factors.

First, in order to promote connectivity and regional cooperation in the three Asias, both SAARC and ECO must work together and overcome hurdles which have so far prevented the economic development and free movement of the people, goods, services and capital. All the three regions share geographical, historical, cultural and religious bonds, yet the approach which should have been pursued by SAARC and ECO for promoting common areas of cooperation, remained missing. So far, there is no joint ministerial meeting or conference between the two regional organisations to discuss how linkages could be forged connecting the three Asias. It is also known to the leadership of Central, South and West Asia that their regions share common issues ranging from water, energy, environmental, educational, scientific, technological areas, along with the challenges emanating from global warming and climate change. All the three regions are exposed to pandemic crisis, thus deepening their human security predicament. Even then, internal and structural contradictions in Central, South and West Asia are such which preclude the transformation of vision of three Asias as a power house into a reality.

Interestingly, the glaciers located in Himalayan, Hindukush, Karakorum and Pamir regions are a source of water resources to the three Asias and because of global warming, there is a serious threat of melting of glaciers and the looming water crisis in all the three regions. This is one area which can be a source of meaningful cooperation in the three Asias because water crisis will lead to food and energy shortages along with reduced agricultural and industrial production. Another major issue which is shared by the regions of Central, South and West Asia is rise of extremism, intolerance, radicalisation of youth, violence and terrorism. These are issues which must be a source of alarm and concern for more than one billion population of the three Asias.

Second, connectivity in the three Asias depends on the vibrant leadership of Central, South and West Asia. Paradoxically, there exists 
leadership vacuum in SAARC and ECO, which is a major impediment for unleashing the process of regionalism. In case of South Asia, the $19^{\text {th }}$ SAARC summit which was to be held in Islamabad in November 2016, it became a victim of Indo-Pak polemics. In September 2016 after the terrorist incident in Uri, the Indian occupied Kashmir, and the so-called surgical strikes, the Indian Prime Minister Narendra Modi threatened to isolate Pakistan in the region and outside. Implementing his threat, India boycotted its participation in the $19^{\text {th }}$ SAARC summit to be held in Islamabad in November 2016. Along with India, Afghanistan, Bangladesh and Bhutan also expressed their inability to participate in SAARC summit. As a result, the SAARC summit is in limbo, which has seriously jeopardised the process of regional cooperation in South Asia. It means there is an acute leadership crisis in South Asia as India's pre-eminent position in the region is only contested by Pakistan. Other members of SAARC lack the ability to take a stand on New Delhi's attempt to impose its suzerainty.

As far as ECO is concerned, there is no SAARC like situation but the member countries lack political will and determination to expedite the process of regionalism. Afghanistan is termed as a major destabilising factor in ECO as the absence of peace in that war-torn country impedes the process of connectivity among the ECO member countries. Due to instability in Afghanistan, Turkmenistan, Afghanistan, Pakistan, India (TAPI) gas pipelines also failed to materialise. Likewise, the ambitious project of Central Asia-South Asia (CASA) for an energy corridor providing electricity from Tajikistan and Kyrgyzstan to Afghanistan, Pakistan and then to India has not been launched because of the turmoil in Afghanistan. Once peace returns to Afghanistan and Indo-Pak relations get normal, one can expect a major trade and commercial breakthrough in the three Asias particularly, between Central and South Asia. Another issue faced by ECO is the US sanctions against Iran and continuous tension between the two countries preventing other members of ECO to enhance their investments, economic and commercial ties with Tehran. Iran-Pakistan gas pipeline, which was earlier called as Iran-Pakistan-India gas pipeline (IPI), was abandoned by New Delhi because of US sanctions against Iran. Therefore, as long as there is tension and confrontation in Iran-US ties, other ECO members will be reluctant to continue their engagements with Tehran. It is yet to be seen if the administration of President Joseph Biden rejoins Iran nuclear deal and gradually lifts sanctions against Tehran. 


\section{Dr.Moonis Ahmar}

Leadership crisis in ECO is also because of the involvement of Turkey in extra-territorial engagements like in Syria and Libya. Turkey, which is the world's $19^{\text {th }}$ largest economy ${ }^{15}$ and a strong player in West and Central Asia, has yet to play a leadership role in ECO. Countries which possess military, economic and political clout in the three Asias are India, Pakistan, Turkey, Iran, Uzbekistan and Kazakhstan but these five countries, instead of focusing to strengthen regional connectivity in Central, South and West Asia, are either involved in mutual discords or extra-regional involvement. Third, inter and intra-state conflicts, which derail the process of progress and development, is a major challenge as far as regional connectivity is concerned. No member of ECO and SAARC is devoid of issues which are of critical nature ranging from ethnic, sectarian, communal, lingual, economic, territorial and resource-based conflicts. Majority of members of the two regional organisations are grappling with the unresolved inter-state conflicts, particularly those between India and Pakistan, Tajikistan and Uzbekistan. Unless issues which trigger violence and the outbreak of armed conflicts are resolved, it will be quite difficult for the three Asias to achieve the goals of regionalism. Unlike Europe and South East Asia, where the process of regionalism and connectivity got an impetus because of relative peace and stability, the case of Central, South and West Asia is different. In the three regions, proliferation in inter and intra-state conflicts tend to derail the process of regional cooperation with India and Pakistan, as the two nuclear states confront each other as a result of the escalation of Kashmir conflict.

The role of Russia as a major player in the three Asias should also be taken into account because the former Soviet Central Asian Republics possess strategic, security and economic ties with Moscow. Russia also has age-old relations with India and has now cordial relations with Iran and Pakistan. In case of Afghanistan, Russia is now involved in a big way for peace in that violence-ridden country.

How ECO and SAARC can play an effective role to help the process of conflict prevention, management, positive conflict transformation and resolution, depends on the political will and determination of members concerned. Ownership of unresolved issues and

\footnotetext{
${ }^{15}$ Hülya Güler, “Turkey to slide back to world's $19^{\text {th }}$ biggest economy by year's end," in Hurriyat Daily News, December 30, 2014.
} 
professional handling of matters which cause instability, political polarisation and tension, can go a long way in creating conditions for a viable peace in the three regions. Finally, role of the non-governmental organisations and civil society groups in strategising efforts for the deradicalisation of youths, counter-extremism, violence, terrorism and dealing with human security issues can help the process of peace and stability in the three Asias. Observance of human rights, ensuring political pluralism and democracy by state actors will mitigate authoritarian culture. Coordinated efforts on the part of governmental and nongovernmental organisations to promote economic, cultural, educational, security and scientific cooperation in Central, South and West Asia will go a long way in transforming regionalism into a reality.

Unfortunately, surge of the culture of civil society has failed to cause any qualitative change in the thinking and mindset of power elites of the three Asias. Democracy, political pluralism, enlightenment, human rights and pro-development approaches, which are supported by civil society groups, should have an impact on the policies of the state. Coercion of religious and ethnic minorities, suppression of gender, youth, children rights remain on the horizon. Recent happenings in India, where the ruling Bharatiya Janata Party (BJP) along with other ultra-right wing Hindu nationalist groups like Shiv Sena, Bajrang Dal, Sang Pariwar and RSS are held responsible for the persecution of religious minorities, particularly the Muslim community under the cover of Citizenship Amendment Act (CAA). It tends to make a mockery of Indian democracy and secularism. State failure to take care of human security like access to the people of clean and safe drinking water, housing, transport, quality education, proper health facilities, employment opportunities along with energy and food means that the regions of Central, South and West Asia are far behind the standards of human development index.

Ameliorating socio-economic conditions of the people must be the priority of regimes in power in the three Asias. For that purpose ECO and SAARC, along with various governmental and non-governmental organisations, must play their role so that human security predicament could be effectively dealt with. When human and social development is the priority of the state and society, the road to peace and stability is already smooth. This is the lesson which one can learn from Europe and South East Asia as governance, development and management of conflicts helped the process of regionalism and connectivity under the leadership of 
EU and ASEAN. SAARC and ECO are now thirty-five years old and by now should have been mature enough to sort out issues, which impede the process of regionalism in the three Asias.

\section{Regionalism for peace and development}

There cannot be two opinions about the essentiality of regional cooperation for peace, security and stability in Central, South and West Asia. Yet what seem to be missing are efforts on the part of two regional organisations representing the three regions i.e. ECO and SAARC, to expedite and strengthen the process of regionalism. The logic and rationality while following the road to regionalism, the countries can strive for peace and development. They can be substantiated on two grounds: First, in the process of regionalism, the ultimate goal is to promote free movement of people, goods, services and capital. With the four characteristics of regionalism taking a practical shape, progress and development in the form of trade, commerce, tourism and cultural connectivity can help to sustain peace and improve the socio-economic conditions of the people.

Unfortunately, no member of ECO or SAARC has tried to seriously understand the dividends of transforming a mindset which obstructs better trade, commercial, travel, educational and cultural ties. The countries representing three Asias are unable to resolve ethnic, sectarian, economic, political, water, environmental and energy issues, including TAPI and other options to enhance regional connectivity. The arguments which are forwarded by those who impede connectivity are: national security threats, terrorism, illegal migration, proliferation of drugs and narcotics. In the name of national security, state actors go an extra mile in tightening visa and travel restrictions while cultural, trade and educational ties also suffer because of that mindset. Several years ago, SAARC agreed to launch South Asian Free Trade Arrangements (SAFTA) in order to promote regional trade and commercial ties. However, SAFTA failed to take off and became a victim of bureaucratic hurdles and Indo-Pak polemics. In EU, where trade among the member countries is around 40 per cent and trade within ASEAN is around 60 per cent, unlike these two regional organisations trade among SAARC countries is less than 10 per cent. Same is the case more or less with other ECO members where the level of intra-regional trade is far less than what is among EU and ASEAN member countries. 
Moreover, due to the non-implementation of SAFTA, South Asia is rightly called as the least integrated region of the world. According to a working paper of Asian Development Bank (ADB) Institute,

"South Asia has an abysmal performance in intra-regional trade as bilateral movement of goods is throttled between India and Pakistan. There is a need to harness the potential of regional cooperation through promoting multilateral experiences of European Union (EU) and Association of Southeast Asian Nations (ASEAN) to address the challenges faced by South Asia. The region should firmly promote South Asian Association for Regional Cooperation (SAARC) to focus on deeper economic integration and trade." 16

The working paper of ADB Institute states: "the economic integration of South Asia could deliver large benefits to its poor population and potential areas of the sub-regional links should include high-market integration, better transport, improved energy, wider information and communication technology and people-to-people connectivity, more investment, and reducing economic vulnerabilities and risks." 17

Vibrant economic, trade and commercial ties can go a long way in mitigating the level of suspicion and mistrust among the countries of that region. Furthermore, viable trade will also help the process of sustainable development thus creating enormous employment and commercial opportunities. That is what primarily prevails in Europe and South East Asia where trade and commercial activities in the two regions not only manage conflicts but also mitigate the level of frustration among the youth. Second, pro-development approach pursued by the regimes of the three Asias is the only solution of dealing with extremism, intolerance, radicalisation of youth, violence and terrorism. Majority of the countries of Central, South and West Asia are squabbling with such issues. Only by unleashing a process of development, both at the social and human level, one can expect around two billion people of the three regions to enjoy the fruits of regionalism and connectivity.

\footnotetext{
${ }^{16}$ Amin Ahmed, "South Asia least integrated region for trade," Dawn (Karachi) March 15, 2020.

${ }^{17}$ Ibid.,
} 


\section{Dr.Moonis Ahmar}

The dividends of regional cooperation and connectivity are not only reflected in peace and development but also in terms of enhanced per capita income, higher GDP and good quality of life. Sharing of knowledge, expertise and skills by ECO and SAARC for a better future is the need of the hour. Countries ranging from Turkey to Bangladesh and from Kazakhstan to Sri Lanka face issues of climate change, global warming, underdevelopment, narcotics, drug-proliferation, extremism, violence and terrorism. Such matters cannot be effectively dealt unless there is a political will and determination on the part of leadership to control forces who want to keep the three regions instable and backward. Minimum steps like easing of visa restrictions and promoting tourism can go a long way in strengthening connectivity in the regions of Central, South and West Asia.

There are numerous opportunities for a viable economic cooperation and connectivity in the areas of travel, information technology, science, education and tourism among the countries of Central, South and West Asia. This needs realisation on the part of the decision-makers to take advantage and pursue a practical approach. Crises and challenges related to issues discussed above also provide an opportunity for bettering situation which can help the process of peace, security and stability in the three Asias. Hope for peace in Afghanistan, which deepened after the signing of Doha agreement on February 29, 2020, between the United States and Taliban, provides a valuable opportunity for augmenting communication linkages between Central, South and West Asia. However, the Biden administration reviewed the timeline mentioned in that agreement for the withdrawal of US forces from Afghanistan and revised it from May 1, 2021, till September 11, 2021. The revised timeline has not been endorsed by the Taliban, which tends to unleash a fresh outbreak of violence in Afghanistan.

As long as Afghanistan remains conflict and violent-ridden prospects for peace in the three Asias would also remain bleak. The future of TAPI, CASA and better trade ties between Central and South Asia depend on peace in Afghanistan. The beneficiaries of peace in Afghanistan will not only be the people of that war-torn country but also its neighbours. Likewise, if relations between the United States and Iran on the one hand, and India and Pakistan on the other are normalised, such a situation will be an added advantage for better connectivity in the three Asias. 
In order to create proper awareness about the importance and significance of regionalism, it is suggested that a course on this concept is offered in all centers of higher learning in Central, South and West Asia. The specialists and experts in these regions must be trained to assist the policy-makers in drawing a feasible roadmap for regionalism and shape it practically. There is a South Asian University in New Delhi and a similar initiative needs to be taken by ECO members by establishing ECO University, which should focus on regionalism and regional connectivity.

\section{Learning lessons from Europe}

While the European experience of regionalism and connectivity cannot be replicated in Central, South and West Asia because of structural contradictions, yet the three regions representing ECO and SAARC can certainly learn lessons as far as the success of transforming Europe from war-devastated continent to a relatively peaceful and prosperous place is concerned. Starting from the European Coal and Steel Community (ECSC) established by France and West Germany to the 1957 Treaty of Rome, which formed European Economic Community to the 1963 Franco-German Treaty of Friendship and Cooperation and the transformation of EEC to European Community (EU) by the Maastricht Treaty of 1992, the road to regional cooperation in Europe has not been smooth but witnessed numerous hurdles.

Some of the lessons which can be learned from the success story of Europe in unleashing the process of regionalism and connectivity are:

1. The role of perceptive, forward-looking and visionary leadership who focused on the present and future of their generations instead of getting bogged down on unresolved issues having historical roots. Unfortunately, the three Asias have not been able to produce visionary leaders like the French President Charles de Gaulle and the West Germany's Chancellor Konrad Adenauer who changed the destiny of Europe by signing the historical Franco-German Treaty of Peace and Cooperation in 1963.

2. Political will, determination and commitment to sustain the process of regional cooperation first under the auspices of European Economic Community and then European Union.

3. To give a practical shape by the founders of EEC and EU to eliminate restrictions on the free movement of people, goods, 
services and capital. As a result, common currency in the form of EURO and visa free travel for the members of EU led to revolutionary changes in Europe promoting connectivity, development, progress and tourism. The vision of a common European Home and Europe from the Atlantic to the Urals motivated those who strived for a meaningful regional cooperation in Europe.

4. Establishing strong institutions, semblance with the institutions established by the EU to promote stability in financial, trade, economic, commercial and political cooperation. The formation of European Central Bank (ECB) and European parliament has played a pivotal role in fiscal/monetary management of EU member countries and to provide representation for policy formulation on political and foreign policy matters. ECB was able to effectively deal with EURO crisis of 2011 by providing bailout package to Greece. ECO and SAARC can thus learn lessons from the EU in taking institutional measures in fomenting the process of regional cooperation and connectivity. There is no SAARC or ECO bank or SAARC or ECO parliament because those who were given the responsibility in the two regional organisations are unable to transform the vision of regional cooperation into practice.

There may be more lessons which ECO and SAARC can learn from the EU but the foremost lesson which one can comprehend from the experience of Europe is the upholding of good governance, rule of law and justice system. In EU countries, there is a growing threat to enlightenment and egalitarianism in the form of populism. It is prevailing in almost all the member countries of the European Union. Similarly, the threat of far-right in targeting immigrants and those having a different cultural way of life is exorbitantly increasing. Yet the rule of law and justice system to a large extent acts as a deterrent against xenophobia and ethnic/religious violence against the minorities. While there is no short cut to regionalism and connectivity, ECO and SAARC members must take note of the fact that without practical approach and sustained process, positive results may not be achieved in the near future.

As rightly said by the founder of modern China, Chairman Mao Zedong, "A journey of thousand miles begins with a single step," is the 
The Challenge Of Regional Connectivity In Central, South And West Asia

key to success of any struggle. Perhaps, ECO and SAARC have not taken note of how struggle with single-minded and consistent approach can yield positive results. The three Asias need to take a single step for a meaningful regional cooperation to be led by SAARC and ECO. 